\title{
Effect of Seasons on Spatial Variability of Rainfall in the Niger Delta, Nigeria
}

\author{
ADEJUWON, JO \\ Department of Water Resources Management and Agrometeorology, Federal University of Agriculture, Abeokuta \\ E-mail: adejoseph2003@yahoo.com
}

\begin{abstract}
The seasons are the important component of rainfall seasonality that determines the flourishing of agricultural and socio-economic activities in the tropics. This study examined the effect of seasons on the spatial variability of rainfall in the Niger Delta, Nigeria. The mean, percentage of variation and coefficient of variation were used to analyze the data. The result showed that the dry season rainfall ranged from 40 to $100 \mathrm{~mm}$ (CV: 49.02 to $151.20 \%)$ and the wet season from 2294.8 to $3670.6 \mathrm{~mm}$ (CV: 22.28 to $110.05 \%$ ). The monthly CV varied from 22.28 to $151.20 \%$ while the annual CV ranged from 11.59 to $32.07 \%$. A little or no variation in space existed in 3 stations in July with the CV range from 34.02 to $34.80 \%$, 3 stations in September with the CV range from 30.40 to $30.70 \%$ and 2 stations in October with the CV range from 32.22 to $32.81 \%$. The CV was highest in January and December with the range of 68.54 to $151.20 \%$ and lowest in May and June with a variation of 22.28 to $54.60 \%$. The study concluded that season controls the extent of variation of rainfall in space in the Niger-Delta.
\end{abstract}

\section{DOI: https://dx.doi.org/10.4314/jasem.v22i10.30}

Copyright: Copyright $\left({ }_{0} 2018\right.$ Adejuwon. This is an open access article distributed under the Creative Commons Attribution License (CCL), which permits unrestricted use, distribution, and reproduction in any medium, provided the original work is properly cited.

Dates: Received: 23 September 2018; Revised: 22 October 2018; Accepted 23 October 2018

Keywords: Rainfall variation, season, spatial variation, coefficient of variation.

Rainfall variability has been the focus of many climate studies in the past, but only a limited quantitative analysis of variability has been undertaken for tropical areas (Ologunorisa and Adejuwon, 2010; Dezfuli and Nicholson, 2013; Nicholson and Dezfuli, 2013). Studies of rainfall variability have been carried out in Queensland (Hendon et al., 2007; Cai et al., 2010; Klingaman et al., 2013), Fiji (Sharman, 1983; Kumar et al., 2014), Israel (Goldreich, 1995; Alpert et al., 2006; Halfon et al, 2006; Levin et al., 2011; Ziv et al., 2014), Spain (Esteban-Parra, 2000; Rodrigo et al., 2000; Lana et al., 2004; Machado et al., 2011), India (Munot and Kothawale, 2000; Krishnamurthy and Shukla, 2000; Rahman et al., 2009), Southern Africa (Nicholson, 2003; Fauchereau et al., 2003) and Tanzania (Mapande and Reason, 2005). Goldreich's (1995) study on analysis of temporal rainfall variability in Israel showed that diurnal patterns of rainfall differ between the southern and northern regions of the country. The spatial distribution of seasonal rainfall depends on the chosen time interval. Fauchereau et al., (2003) reported that some regions have experienced a shift towards more extreme rainfall events in recent decades in Southern Africa. Close examination reveals that rainfall variability has experienced significant modifications, especially in the recent decades. Variations in rainfall stem from geographical factors, the interaction of topographical features and atmospheric elements and motions.
Variations in such atmospheric conditions need investigation. A number of studies have attempted to relate rainfall variation to variations in the solar cycle such as sunspot cycles (Meehl et al., 2009; Wang and Zhao, 2012) and solar activity in relation to Maunder Minimum period (Esteban-Parra, 2000). Other investigators related variations in rainfall to changes in upper air pressures (Anderson et al., 2006; Compo et al., 2006). Notable variation is observed in the incidence of precipitation on a diurnal basis (Munot and Kothawale, 2000). Although this may exert less influence particularly on agricultural activities as compared to the seasonal rainfall regime, it was recognized as playing a vital role particularly in the climate of the tropical region (Fauchereau et al., 2003). For instance, daily rainfall during the day is vulnerable to considerable evaporative loss in this part of the world. Despite the considerable variation observed in the incidence of a day, there are some predictable characters in diurnal rainfall distribution. Sharman (1983) revealed that $62 \%$ of the precipitation in Fiji occurred during the daytime and the remaining $38 \%$ falls during the nighttime. The seasons (dry and wet) are the important component of rainfall seasonality that determines the flourishing of agricultural and other socio-economic activities in the study area (Adejuwon, 2008). Ayoade (1988) reported that seasonal precipitation distribution is equally as important as the total amount in the tropical and extra- 
tropical region. The increasing seasonality in the rainfall of Nigeria with distance from the coast is a part of the continental scale latitudinal pattern (Ayoade, 1970). In spite of the importance of the seasons and rainfall variability, no study has been carried out on the effect of seasons on the spatial variability of rainfall in the Niger Delta. Few literatures in Nigeria (Adedokun, 1978; Olaniran, 1983; Adefolalu, 1986; Adelekan, 1998) concentrated on the spatial distribution of rainfall with no attempt on the effect of the seasons and made use of too few stations that were not sufficient to represent the rainfall patterns of a large area such as Niger Delta. For instance, Adelekan (1998) included Port Harcourt station only in her study. This study is an attempt at filling the gap created by insufficient literature on the effect of seasons on the spatial variability of rainfall in the study area.

\section{MATERIALS AND METHODS}

Study Area: The study area (Fig 1), Niger Delta is one of the largest deltas in the world (Singh et al, 1995) and covers a land area of over $29,100 \mathrm{~km}^{2}$ (Ogunkoya and Efi, 2003). It lies between longitude $5^{\circ} 05^{\prime} \mathrm{E}$ and $7^{\circ} 35^{\prime} \mathrm{E}$ and latitude $4^{\circ} 15^{\prime} \mathrm{N}$ and $6^{\circ} 01^{\prime} \mathrm{N}$ (Figures 1). However, Niger Delta lies mainly within the wet equatorial climatic region, but in its northern extremities, the climate is the tropical wet and dry type. It falls within the coastal zone. Between 9-10 months in the year, the climate of the coastal zone is dominated by the tropical maritime air mass while the remaining 2-3 months of the year is under the influence of the dry tropical continental air mass. Over two-thirds of the area, which terminated at $7^{\circ} \mathrm{E}$ was dominated by little dry season (LDS) in the mid-wet season of July/August months (Adejuwon and Odekunle, 2006; Gbuyiro and Adefisan, 2007; Adejuwon, 2010). The mean annual rainfall decreases from about $4500 \mathrm{~mm}$ around the coastal margin to about $2000 \mathrm{~mm}$ around the northern fringe of the study area (Adejuwon, 2008). The thermal regime as indicated by mean annual temperature exhibits a marked uniformity. The annual range of temperature for most stations during the year is from $27^{\circ} \mathrm{C}$ along the coastal fringe to about $28{ }^{\circ} \mathrm{C}$ in the interior of the study area (Emielu, 2000; Mistry, 2000). The relative humidity decreases slightly in the northern fringe where it averages about $80 \%$ as compared with $85 \%$ in the south.

Sources of Data: The data used for this study consist of monthly archival rainfall data from 1931-1997. The data were collected from the Nigeria Meteorological Agency (NIMET), Oshodi, Lagos and International Institute of Tropical Agriculture (IITA), Ibadan. The data was collected from the selected stations shown in Table 1.

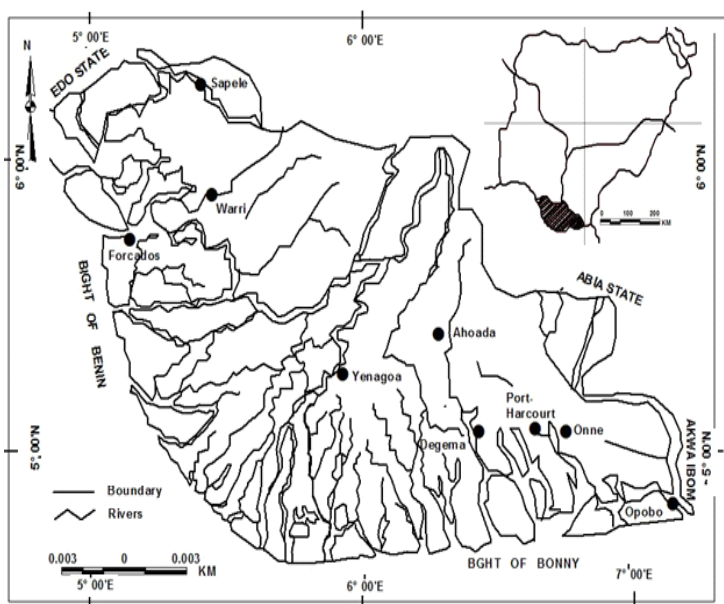

Fig 1: The Map of Niger Delta showing the sampling locations

Table 1. Location of Stations at Nigeria Meteorological Agency, Oshodi, Lagos and International Institute of Tropical Agriculture

\begin{tabular}{|c|c|c|c|c|}
\hline S/No & Station & Lat. $\left({ }^{\circ} \mathbf{N}\right)$ & Long ${ }^{\circ} \mathbf{E}$ & $\begin{array}{l}\text { Altitude } \\
\text { (M) }\end{array}$ \\
\hline 1 & Sapele & $05^{\circ} 55^{\prime}$ & $05^{\circ} 41^{\prime}$ & 6.1 \\
\hline 2 & Warri & $05^{\circ} 31^{\prime}$ & $05^{\circ} 44^{\prime}$ & 6 \\
\hline 3 & Forcados & $05^{\circ} 55^{\prime}$ & $05^{\circ} 26^{\prime}$ & 3.0 \\
\hline 4 & Yenegoa & $05^{\circ} 06^{\prime}$ & $06^{\circ} 16^{\prime}$ & 5.0 \\
\hline 5 & Ahoada & $04^{\circ} 51^{\prime}$ & $06^{\circ} 39^{\prime}$ & 9.06 \\
\hline 6 & $\begin{array}{l}\text { Port- } \\
\text { Harcourt }\end{array}$ & $04^{\circ} 45^{\prime}$ & $07^{\circ} 01^{\prime}$ & 9 \\
\hline 7 & Degema & $04^{\circ} 52^{\prime}$ & $06^{\circ} 46^{\prime}$ & 3 \\
\hline 8 & Onne & $04^{\circ} 34^{\prime}$ & $07^{\circ} 02^{\prime}$ & 11.35 \\
\hline 9 & Opobo & $04^{\circ} 57^{\prime}$ & $07^{\circ} 35^{\prime}$ & 3.1 \\
\hline
\end{tabular}

Analysis of Data: Data were analyzed using mean and percentage of variation for the monthly, annual and seasonal rainfall, and coefficient of variation $(\mathrm{CV})$ for spatial variation. Earlier studies on spatial variability of rainfall used correlation analysis (Jackson, 1978), principal component analysis (Basalirwa, 1995), elementary linkage analysis (Gregory, 1965; Adelekan, 1998). However, the coefficient of variation (CV) was employed in this study as the analytical tool to determine spatial variations in monthly and annual rainfall.

$\mathrm{CV}$ measures the percentage of deviation from the mean value (Olsson, 1983), and is preferred to other methods because of its advantages. The value of the $\mathrm{CV}$ allows comparison to be made between datasets whose scatter is measured in different units or, like the regional data, have different orders of magnitude (O'Brien, 1992). This technique is also useful when it is desired to plot variability on a map because variations appear as readily comparable differences. The technique is expressed as:

$$
C V=\frac{\sigma}{\bar{x}}
$$

Where: CV is the coefficient of variation, $\sigma$ is the standard deviation and $\bar{x}$ is the mean rainfall. 


\section{RESULT AND DISCUSSION}

Figure 2 shows the mean monthly values of rainfall in some stations in the Niger Delta, Nigeria. All the stations recorded a very low rainfall of less than 50 $\mathrm{mm}$ in January and December. The lowest of 25.42 $\mathrm{mm}$ rainfall in the series was recorded at Onne in January. The dry season period with the lower amount of rainfall (40 to $100 \mathrm{~mm}$ ) experienced the highest spatial variability (CV: 49.02 to $151.20 \%$ ) while the wet season with a high amount of rainfall (2294.8 to $3670.6 \mathrm{~mm}$ ) experienced the lowest spatial variability (CV: 22.28 to $110.05 \%$ ). The contribution of the dry season rainfall to the annual total was $1.35 \%$ to $3.90 \%$ (Table 2). The CV was highest in January and December with the range of 68.54 at Yenagoa to $151.20 \%$ at Ahoada. During the dry season in December, the coastal area is under the influence of the cT air mass. In January, the mT predominates in few locations and drives the ITD inlands (Adelekan, 1998; Adejuwon, 2008). This explains why the rainfall amount was more and the wet season was longer during the course of the year. Studies have also indicated the evidence of some disturbance lines along the ITD locations (Eldridge, 1957). The disturbance lines are prevalent in the Niger Delta at the beginning and towards the end of the wet season. The $\mathrm{CV}$ ranged from $50 \%$ to $100 \%$ in February and November, but mostly below $50 \%$ from March to October, a core wet season period with rainfall variation of between 2000 $\mathrm{mm}$ and $4000 \mathrm{~mm}$. It was observed that the stations in the same climatological zone varied greatly in space during this period. February and November rainfall was also highly variable because the months marked the onset and retreat of rainfall for most stations in the region (Adejuwon, 2012). From March, the rainfall increased while the $\mathrm{CV}$ decreased till June. The low CV of less than $33 \%$ (except Degema $-34.40 \%$ and Port Harcourt $-54.60 \%$ ) at this period implied that the ecosystem is at equilibria. The non-equilibrium systems have the CV of $33 \%$ or higher (Kgosikoma, 2006).

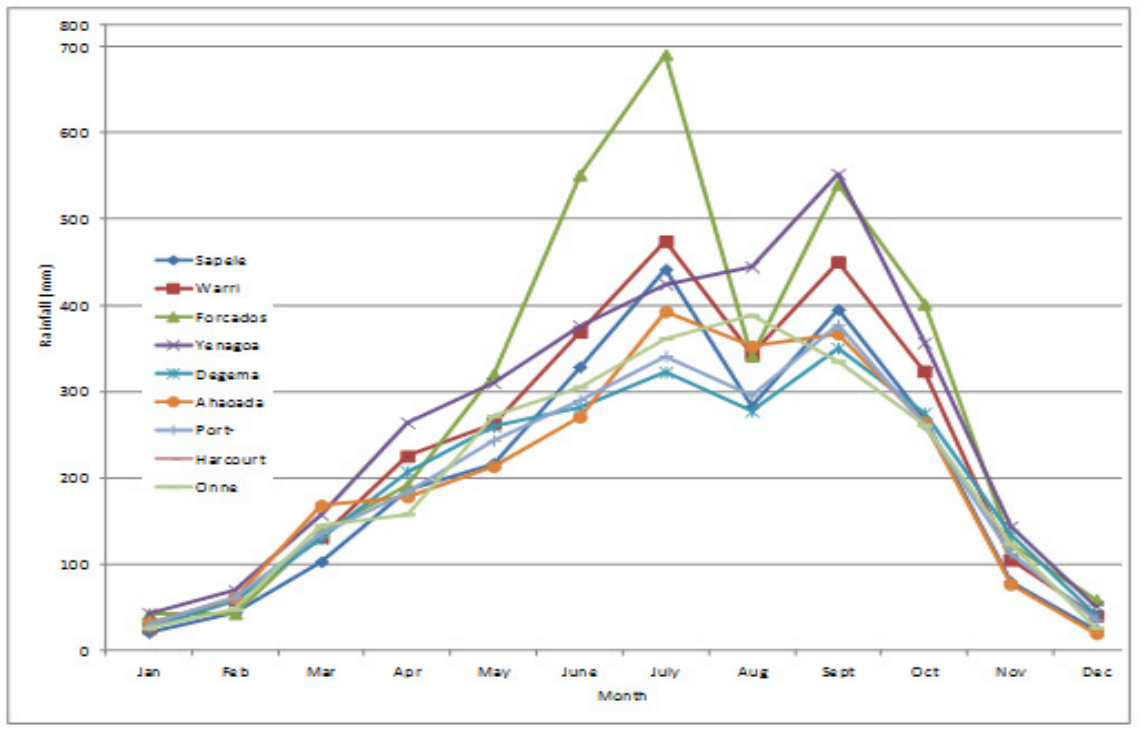

Fig 2: Mean monthly values of rainfall in some stations in Niger Delta, Nigeria

Table 2: Dry and Wet season rainfall and their contributions in the Niger Delta.

\begin{tabular}{llllll}
\hline Station & $\begin{array}{l}\text { No. of } \\
\text { Years }\end{array}$ & $\begin{array}{l}\text { Dry season rainfall Percentage } \\
\text { (Dec-Jan/Feb) }\end{array}$ & \multicolumn{2}{l}{$\begin{array}{l}\text { Wet Season rainfall Percentage } \\
\text { contribution }\end{array}$} \\
& 67 & 87.9 & 3.68 & 2301.0 & 96.32 \\
Sapele & 67 (March.-Nov). contribution \\
Warri & 67 & 66.0 & 2.36 & 2741.8 & 97.64 \\
Forcados & 67 & 85.0 & 2.47 & 3357.3 & 97.53 \\
Yenagoa & 37 & 42.7 & 1.34 & 3148.9 & 98.66 \\
Ahoada & 67 & 65.9 & 2.79 & 2294.8 & 97.21 \\
Port-Harcourt & 25 & 50.6 & 2.12 & 2343.0 & 97.88 \\
Degema & 67 & 64.3 & 2.73 & 2297.2 & 97.27 \\
Onne & 21 & 99.1 & 4.05 & 2348.7 & 95.95 \\
Opobo & 67 & 96.7 & 2.57 & 3670.6 & 97.43 \\
\hline
\end{tabular}




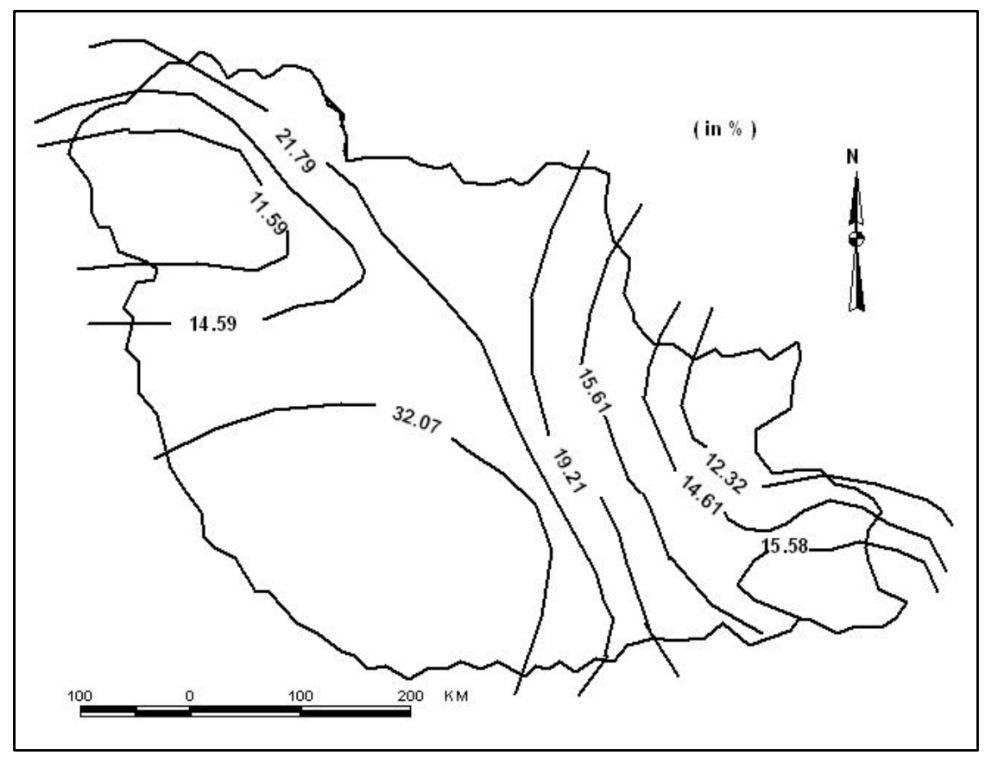

Fig 3: Spatial variation of mean annual rainfall in the Niger Delta

The lowest value in the series was observed in the months of May and September. In fact, there was little or no spatial variation of rainfall in Warri, Onne and Opobo in July, Warri, Degema, and Port Harcourt in September, and the pair of Warri and Onne as well as Port Harcourt and Degema in October. For instance, the CV of Warri, Degema, and Port Harcourt was $30.64 \%, 30.70 \%$ and $30.40 \%$ respectively in September. Rainfall was highest in July and September, being the double-maxima months of rainfall in the region. The highest amount of $690.97 \mathrm{~mm}$ rainfall was recorded at Forcados in July during the period under investigation. The CV of July and August was high while that of September and October was low. The reason for the high CV in July and August was due to the occurrence of the LDS at this period. The LDS phenomenon is a short period of semi-dry season associated with a decline in rainfall in mid-wet season south of $10^{\circ} \mathrm{N}$ in spite of the moist airflow over the area (Adejuwon, 2010). The LDS is associated with the temporary absence of Africa Easterly Jet (AEJ) and El-Nino/southern oscillation (ENSO) (Adedokun, 1978; Akande, 2013). The mean annual rainfall ranged from $2361 \mathrm{~mm}$ at Port-Harcourt to $3767 \mathrm{~mm}$ at Opobo, while mean annual CV varied from $11.59 \%$ at Warri to $32.07 \%$ at Yenagoa (Figure 3). Few stations showed little variation while Opobo and Ahoada with the CV of $15.58 \%$ and $15.61 \%$ respectively did not vary in space. The mean annual rainfall for the region varied from $2000 \mathrm{~mm}$ to 4000 $\mathrm{mm}$.

Conclusion: This study has shown that the highest rainfall was not more than $100 \mathrm{~mm}$. Rainfall was more variable in space in the dry season than the wet season and on monthly than the annual basis. Spatial variation of rainfall ranged from low to high in the region, with few stations indicating little or no variation in space in July, September and October. The dry season contributed 1.34 to $4.05 \%$ while and the wet season contributed 95.5 to $98.66 \%$ rainfall to the annual total. The study concludes that season is a determinant of spatial variability of rainfall.

\section{REFERENCES}

Adedokun, JA (1978). West African Precipitation and Dominant Atmospheric Mechanisms, Arc Met. Geog.

Biok l, Ser 27, 289-310.

Adefolalu, DO (1986). On the Nature of Sahelian Drought as evident from Rainfall Regime of Nigeria (1911-1983). World Meteorological Organization Report.

Adejuwon, JO (2008). The Onset, Duration and Retreat of Rainfall in the Niger Delta Belt, Nigeria. The

Inter. J. Meteorology, 33(333):303-309.

Adejuwon, JO (2010). Analysis of Rainfall Trend during the Little Dry Season in Southwestern Nigeria.

J. Meteorology and Climate Sci. 8(2): 64-70.

Adejuwon, JO (2012). Rainfall seasonality in the Niger Delta Belt, Nigeria. J. Geo. Region. Plan. 5(2): 51-60. 
Adelekan, IO (1998). Spatio-temporal variations in thunderstorm rainfall over Nigeria, Int. $J$. Climatol. 18:

1273-1284

Akande, AS (2013). West Africa Meteorology Lecture notes $2.724 \mathrm{pp}$

Alpert, P; Ilani, R; Da-Silva, A; Rudack, A; Mandel, $M$ (2006). Seasonal prediction for Israel winter precipitation based on northern Hemispheric EOF, MERCHAVIM special issue in honour of Prof. Arie Bitan, 397-412.

Anderson, BT; Kanamaru, H; Roads, JO (2006). Variations in the Summertime Atmospheric Hydrologic Cycle Associated with Seasonal Precipitation Anomalies over the Southwestern United States". J. Hydrometeor, 7(4), 788-807

Ayoade, JO (1988). Introduction of Climatology for the Tropics, Abiprint and Palc Limited, Ibadan.

Basalirwa, CK (1995). Delineation of Uganda into climatological rainfall using the method of principal component analysis. Int. J. Climatol., $15,1161-1177$.

Cai, W; Rensch, P; Cowan, T; Sullivan, A (2010). Asymmetry in ENSO Teleconnection with Regional Rainfall, Its Multidecadal Variability, and Impact. J. Climate, 23, 4944-4955.

Compo, GP; Whitaker, JS; Sardeshmukh, PD (2006). Feasibility of a 100-Year Reanalysis Using Only Surface Pressure Data, Bulletin of American Meteorological. $\quad$ Society, 87(2):175-190.

Dezfuli, AK; Nicholson, SE (2013). The Relationship of Rainfall Variability in Western Equatorial Africa to the Tropical Oceans and Atmospheric Circulation. Part II: The Boreal Autumn, J. Climate, 26, 66-84.

Emielu, SA (2000). Senior Secondary Geography. Geographical Bureau Nigeria Limited, Ilorin. pp 71-72.

Eldridge, RH (1957). A Synoptic Study of West Africa disturbance lines, Quart. J. Royal Meteorol. Soc. 83, 303-314.

Esteban-Parra, MJ (2000). Rainfall variability in southern Spain on decadal to centennial time scales, Int. J.
Climatol, 20:721-732.

Fauchereau, N; Trzaska, S; Rouault, M; Richard, Y (2003). Rainfall Variability and Changes in Southern

Africa during the $20^{\text {th }}$ century in the Global Warming Context. Nat. Hazards. 29(2), 139-154.

Goldreich, Y (1995). Temporal Variation of Rainfall in Israel. Climate Res. 5(2) 167-179.

Gregory, S (1965). Rainfall over Sierra-Leone. Research Paper no 2, Department of Geography, University of Liverpool, 58pp

Halfon, N; Kutiel, H; Ziv, B (2006). The Rain Spells in Israel-Major Spatial Patterns and their Synoptic Conditions, 8th Plinius Conference on Mediterranean Storms and Extreme Events in an Era of Climate Change, Dead Sea, 17-20.

Hendon, HH; Thompson, DWJ; Wheeler, MC (2007). Australian rainfall and surface temperature variations associated with the Southern Hemisphere annular mode. J. Clim., 20, 24522467

Jackson, IJ (1978). Local differences in the pattern of variability of Tropical rainfall; some characteristics and implications. $J$. Hydrol., 38, 273-283.

Kgosikoma, OE (2006). Effects of Climate Variability on Livestock Population Dynamics and Community Drought Management in Kgalagadi, Botswana. M. Sc Thesis, Norwegian University of Life Sciences (UMB), Noragric, Norway.

Klingaman, NP; Woolnough, SJ; Syktus, J (2013). On the drivers of inter-annual and decadal rainfall variability in Queensland, Australia, Int. J. Climatol., 33 (10), 2413-2430. DOI: $10.1002 /$ joc. 3593

Krishnamurthy, V; Shukla, J (2000). Intra-seasonal and Inter-annual Variability of Rainfall over India. J. Climate, 13, 4366-4377.

Kumar, R; Stephens, M; Weir, T (2014). Rainfall trends in Fiji. Int. J. Climatol 34 (5): 1501-1510.

Lana, X; Mart'inez, MD; Serra, C; Burguẽno, A (2004). Spatial and temporal variability of the daily rainfall regime in Catalonia (northeastern Spain), 1950-2000. Int. J. Climatol., 24: 613-641. 
Levin, Z; Halfon, N; Alpert, P (2011). Reply to comment by Ben-Zvi, A., D. Rosenfeld and A. Givati on the paper-Levin, Z., N. Halfon and P. Alpert, Reassessment of rain experiments and operations in Israel including synoptic considerations. Atmos. Resource. 99, 593-596.

Machado, MJ; Benito, G; Barrientos, M; Rodrigo, FS (2011). 500 Years of rainfall variability and extreme hydrological events in southeastern Spain drylands. J. Arid Environ 75, 1244-1253.

Mapande, AT; Reason, C (2005). Inter-annual rainfall variability over Western Tanzania, Int. J. Climatol., 25, 1355-1368

Meehl, G; Arblaster, J; Matthes, K; Sassi, F; Loon, HV (2009). Amplifying the Pacific Climate System Response to a Small 11-Year Solar Cycle Forcing. Sci., 325 (5944):

Mistry, J (2000). World Savanna - Ecology and Human Use. Pearson Education Limited. England, 20-25. 108-131

Munot, AA; Kothawale, DR (2000). Intra-seasonal, inter-annual and decadal-scale variability in summer monsoon rainfall over India, Int. J. Climatol., 20, 1387-1400.

Nicholson, SE (2003). Comments on "The South Indian Convergence Zone and International Rainfall Variability over Southern Africa”. J. Climate, 16 (3): 555-562.

Nicholson, SE; Dezfuli, AK (2013). The Relationship of Rainfall Variability in Western Equatorial Africa to the Tropical Oceans and Atmospheric Circulation. Part I: The Boreal Spring, J. Climate, 26, 45-65.

Nicholson, SE; Kim, J (1997). The relationship of the El Niño- Southern oscillation to African rainfall. Int. J. Climatol., 17: 117 - 135.

O"Brien, L (1992). Introducing Quantitative Geography: Measurement, Methods and Generalized Linear Methods. London, Routledge
Olaniran, OJ (1983). The onset of rain and start of growing season in Nigeria. Nig. Geog. Jour. 26 (1 and 2): 81-87.

Ologunorisa, TE; Adejuwon, JO (2010). Inter-annual rainfall variability in the Niger Delta, Nigeria. The Inter. J. Meteorol. 35 ( 345): 22-30.

Olsson, L (1983). Desertification or climate? The investigation regarding the relationship between land degradation and climate in the Central Sudan. (Lund Studies in Geography Series) Physical Geography, 60:1-35.

Rahman, SH; Sengupta, D; Ravichandran, M (2009). Variability of Indian summer monsoon rainfall in daily data from gauge and satellite. Journal of Geophysical Research: Atmospheres (19842012), 114, D17.

Rodrigo, FS; Esteban-Parra, MJ; Pozo-Va' Zquez, D; Castro-Diez, Y (2000). Rainfall variability in Southern Spain on decadal to centennial time scales. Int. J. Climatol. 20: 721-732

Sharman, SK (1983). Diurnal Variation of Rainfall at Nandi Airport, Fiji, Weather, 38(8): 231-239.

Singh, J; Moffat, D; Linden O (1995). Defining an Environmental Development Strategy for the Niger-Delta, vol. 11, Industry and Energy Operations Division, West Central Africa Department, World Bank.

Wang, J; Zhao, L (2012). Statistical tests for a correlation between decadal variation in June precipitation in China and sunspot number. $J$. Geophysic. Res.: Atmos. (1984-2012). 117, Issue D23, DOI: 10.1029/2012JD018074

Ziv, B; Saaroni, H; Pargament, R; Harpaz, T; Alpert, $P$ (2014). Trends in rainfall regime over Israel, 1975-2010, and their relationship to large-scale variability. Reg. Environ. Change, 14: 1751-1764. 